\title{
The Informed Consent/Assent from the Doctrine of the Mature Minor
}

\author{
Anderson Díaz-Pérez ${ }^{1}$, Arley Denisse Vega Ochoa ${ }^{2} \&$ Zoraima Romero Oñate ${ }^{2}$ \\ ${ }^{1}$ Universidad Simón Bolívar, Departamento de Ciencias Sociales y Humanas, Barranquilla, Colombia \\ ${ }^{2}$ Universidad Popular del Cesar, Facultad de Ciencias de la Salud, Valledupar, Colombia \\ Correspondence: Anderson Díaz-Pérez, Universidad Simón Bolívar, Departamento de Ciencias Sociales y \\ Humanas, Barranquilla, Colombia. ORCID. http//:orcid.org/0000-0003-2448-0953. E-mail: \\ ander2711@gmail.com; adiaz72@unisimonbolivar.edu.co; Arley Denisse Vega Ochoa, Universidad Popular del \\ Cesar, Facultad de Ciencias de la Salud, Valledupar, Colombia. ORCID. https://orcid.org/0000-0002-9483-2101. \\ E-mail: arleydenisse@gmail.com
}

Received: June 14, 2018 Accepted: July 15, 2018 Online Published: July 25, 2018

doi:10.5539/gjhs.v10n8p124

URL: https://doi.org/10.5539/gjhs.v10n8p124

\begin{abstract}
It is necessary to recognize the child as an active moral subject in making decision process related to his health or his participation in research. The taking of informed consent as a communication process should tend to respect the autonomy and dignity of the child considered mature or not, taking their decisions seriously and not just an assent as a normative principle of mere legal aspect. It describes theoretical elements that can be used as tools to have an approach to the moral development of the child from the principle of responsibility according to the degree of emancipation. The objective is to provide a description of the most relevant aspects about the informed consent process in the mature child and their right to be informed to agree or consent. We searched the databases such as: PROQUEST, MEDLINE, LILACS and PUBMED, analyzing 51 articles. For the organization of the information, the SLIDING methodology was used: sort, label, integrate and prioritize. It was concluded that the ability to assent of the child considered mature or not should be evaluated under objective parameters and not simply under the perception of the doctor or researcher. Finally, it is necessary to design strategies to promote the autonomy, respect and dignity of the child based on the same practices at the time of informed consent.
\end{abstract}

Keywords: consent/informed assent, children, adolescents, moral development, capacity, dilemmas, bioethics, dignity, respect, autonomy

\section{Introduction}

The analysis carried out in this article allows researchers/clinicians to think about the moral system that encompasses the underage person to consider him as a subject of rights at the time of taking the informed consent. The minor who shows maturity to make a decision regarding their participation in research or treatment, could mean an ethical issue for those who take informed consent, which requires the clinical professional or researcher prudence not to underestimate the autonomy of the child (Lyon, 1987), but also, the obligation to apply the regulations of each country that describes when the child becomes an adult. To consider that a underage person is mature, he must verify an understanding of the scope and meaning of his actions (Blázquez, 2014).

Aristóteles argues that "young people can be geometricians and mathematicians and wise in things of that nature, and instead, do not seem to be prudent" (Guillén, 1997, p. 6; Martínez \& others, 2001, Capítulo VI 8: a 1142a14-21). That is, moral virtue par excellence and prudence is reached late (later?). Although it also describes, that young people by their ability to be geometers and mathematicians come to understand [logical] situations, and be responsible for their own actions (I may misunderstand but it reads contradictory? Also , and this is fascinating, given the quote of course, children can comprehend, even of course do logical analysis, but is it enough given consent which implies comprehension on future and abstract concepts) (Guillén, 1997, p. 6). Propending for your care with responsibility thinking about your future.

Goodwin points out that unlike consent, informed consent has a special connotation, since it requires two actors: the minor and the legal guardian, which means; that is not a decision made only by the minor (Goodwin \& Duke, 2011). It is for this reason that it is necessary to clarify the idea of the minor from the doctrine of the mature minor, as well as the main elements to take into account when taking informed consent for clinical and for research, considering their right to be informed regardless of age, socio-cultural context or legal aspects, achieve the active 
participation of the child with a deliberative approach, free of extreme paternalism, priestly or ingeneril, with a high ethical and moral responsibility on the part of the one who takes the informed consent as a process real communication.

\section{Method}

A review was made in different high scientific impact databases such as: PROQUEST, MEDLINE, LILACS and PUBMED. The search was systematized in English and Spanish languages, mediated by the impact of the articles (citations) as by the use of keywords such as: biomedical research, mature minor, children and informed consent as main inclusion criteria, then sort them according to the number of words. The search was open in relation to time. We found 102 articles and after using the combination of the descriptors, 51 articles that met the inclusion criteria were finally analyzed.

Guirao-Goris, Olmedo Salas, \& Ferrer Ferrandis, (2008) propose a way to organize and analyze the information which they called SLIDE that consists of: 1. Order: Articles were ordered per year and with more than three keywords together and impact of the citation. 2. Labeling: the articles were labeled with two analysis groups in mind. A first group in relation to the informed consent and a second group related to the doctrine of the mature minor. 3. Integration: each of the two groups was related to clinical and research topics, and finally the prioritization: it was determined as the most important groups those that considered the mature minor doctrine and communication process, as well as capacity or moral maturity.

\section{Consent From the Doctrine of the Mature Minor Recognition of His Autonomy}

According to Jacob (2005, p. 157); "you cannot confuse moral maturity with moral and legal capacity", that is, the moral maturity of a person must be measured by their formal abilities to judge and assess situations, not by the content of the values that assumes or manages (Díaz \& Pérez, 2007; Gracia et al., 2001)

In relation with was mentioned above, Aresté, Paradero, \& Fernández, (2013) argue that there is very little consensus and therefore difficulties on the side of pediatricians and researchers to assess the child's competence, where the difficulty lies not only in the different factors to consider when taking the informed consent, as for example: no sufficient theoretical and practical preparation in professionals to perform assessments or standardized systematic procedures to assess the moral capacity of the child, being driven by the perception and sensitivity of each professional or researcher regarding the child's autonomy to consider it mature. The process related to informed consent is more complex compared to consent, because it delivers many more dilemmas due to the child's vulnerability condition and, therefore, contribute to the development of the child's autonomy (Alderson, 2007; Morrow \& Richards, 1996).

Wendler \& Shah (2003, p. 1), refers the word consent as a communication process in which basic information is given to the child about a research study or treatment, likewise they are asked to participate in the decision making, taking as primary principles the autonomy and non-maleficence, which would lead to consider the child in the decision making from 12 years old, keeping in mind the elements of analysis proposed by the Royal College of Pediatricians of England ("Witholding.pdf_40818793.pdf", s. f., pp. 1-43)?, which could be summarized in the need to communicate to the child about the medical or research aspects in the most appropriate way, keeping in mind their level of understanding, helping to the child to feel as a central character in the actions taken related to his/her health. For this, it is necessary to listen to the minor to diminish his fears, doubts and worries, but also to consider his/her observations or opinions regarding what it is important and make him/her comprehend that will be taken into account according to the degree of responsibility for the treatment or investigation, and thus consider him/her as an active and morally competent subject. The proposed study (Weithorn \& Campbell, 1982), indicates other levels of participation, such as: providing information about the illness, treatment and medical procedures to the minor, as well as making the decision as a whole (trinomial: medical personnel-minor-family). On the other hand Drane (1999), proposes a methodology whose observation criterion is the proportionality between the severity of the decision and the degree of moral competence, which must be taken into account when evaluating the ability to make or not a decision by the mature minor or adult (Drane, 1999, pp. 163-176) (See Table 1). 
Table 1. Mobile scale model (Drane, 1999)

\begin{tabular}{llll}
\hline $\begin{array}{l}\text { Levels of } \\
\text { competence }\end{array}$ & $\begin{array}{l}\text { Competence } \\
\text { criteria }\end{array}$ & States that Suppose Incompetence & States that Suppose Competence \\
\hline & & & \\
& & & \\
& Unconsciousness; severe mental & Children $>$ of 10 years old, mild \\
Revel 1. Easy and & $\begin{array}{l}\text { Minimum } \\
\text { requirements: }\end{array}$ & $\begin{array}{l}\text { total disorientation; severe senile } \\
\text { dementia; autism; Psychotic defenses }\end{array}$ & $\begin{array}{l}\text { obtundation (?); mild senile } \\
\text { dementia; states included in levels }\end{array}$ \\
Treatment & Consciousness & $\begin{array}{l}\text { (Denial of him/her self and of the } \\
\text { and Assent }\end{array}$ & $\begin{array}{l}\text { 2 and 3 (A and B) } \\
\text { situation, Delusional projection) }\end{array}$
\end{tabular}

Possible Medical Decisions (In Competent Subjects)

Consent in case of:

- Effective Treatment for Acute Disease

- Correct Diagnosis

- Benefit High/Low Risk

- $\quad$ Limited Alternatives

- $\quad$ Serious

Disorder/Intense Suffering/Immediate Life Threat

Rejection in case of:

- Ineffective treatment

Consent or Rejection of:

- Chronic

\section{Disease/Doubtful}

Severe affective disorders; phobia to Medium the treatment; mutism; loss of fixation
Level 2. Less Safe Treatments
Requirements:

Understanding and Choice memory; Thought disorder (ignorance, incoherence, delirium, hallucination, delirium, states included in level 1 (A and B)
Adolescents $>16$ years old; mild mental retardation; personality disorders (narcissist, borderline and obsessive)? (I agree low functioning personality disorders may prove complex); States included in level 3 (A and B)
- Acute Disease With Uncertain Result Treatment

- Balance Between Risks And Benefits (Uncertain Effectiveness With Risks Or Serious Disadvantages)

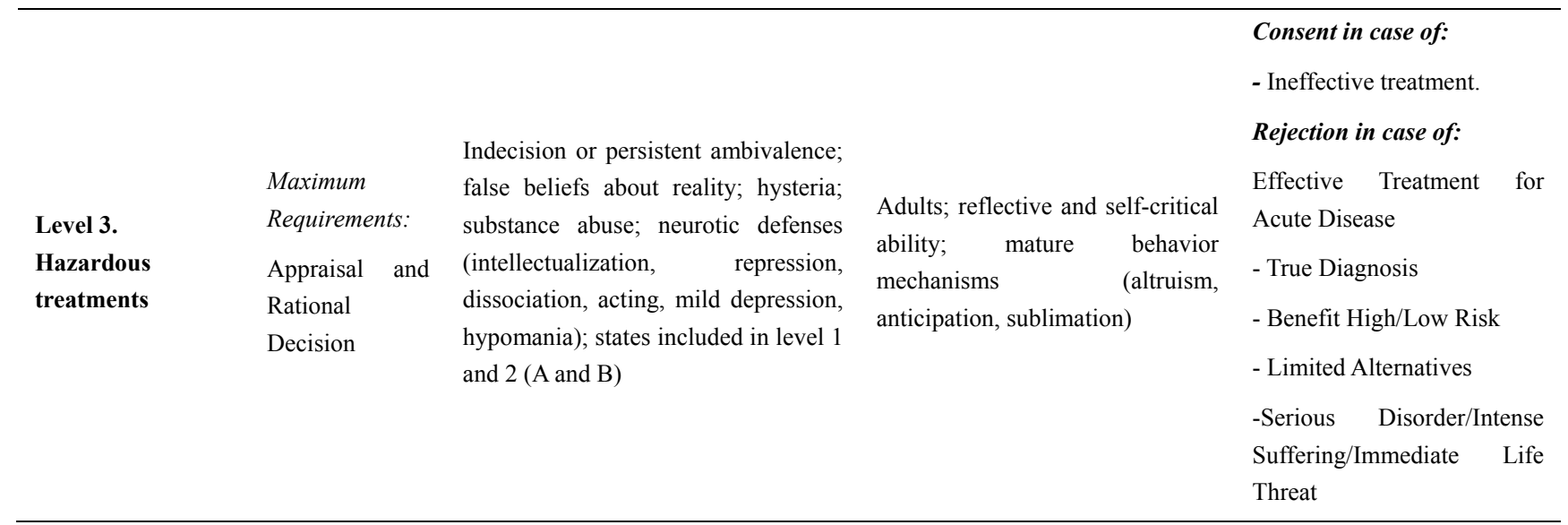

According to (Drane, 1999) the ethical analyzes carried out emphasize more on the responsibility of the clinician in not revealing the information and maintaining a healthy interaction with the patient free of coercion, however, nowadays the questions about the capacity of a patient to consent or assent are more frequent. The study proposed by (Appelbaum \& Roth, 1982; Roth, Appelbaum, Sallee, Reynolds, \& Huber, 1982) Peter formulates criteria which can be summarized as the rational understanding of the facts and the consequences of decisions beyond what Appelbaum proposes as "appreciation of the nature of their situation" (Appelbaum \& Roth, 1982, pp. 910-913) which can be simplified as "the understanding of the facts" (Roth et al., 1982), that is to say; a factual compression. This could be considered as the recognition of the importance for improving the health of the minor the adherence to the treatment, to weigh the desires proper of his age with the supreme good to reach his well-being 
with the minimum possible pain and greater adaptation to the illness under the sociocultural context surrounding the minor.

\section{Moral Capability of the Minor Considered Mature}

The ability of the mature minor to decide, as mentioned, is not equal to the legal aptitude, but does not exempt the clinician or researcher from their moral duty to assess the child's moral ability for making a decision (Ecoffey \& Dalens, 2003, pp. 205-208).

The Presidential Commission for the Study of Ethical Problems and in Biomedical and Behavioral Research, mentions that the ability or competence lies in the fact that the person despite whether is an adult or underage must also have a set of values and goals, the ability to communicate and demonstrate understanding of information, as well as the aptitude for reasoning and deliberation about decisions (Drane, 1999, p. 164; Owens, 1977, p. 104).

According to (King \& Cross, 1989, p. 10), respecting the autonomy of the minor is a moral duty rather than a legal one. That is to say, that the decision making ability of the minor can vary in relation to the age (Ecoffey \& Dalens, 2003), therefore he should not be exempt from his right to agree (Fluke, Baumann, Dalgleish, \& Kern, 2014, pp. 464-465).

Health sciences professionals and researchers may presume a priori that children and adolescents have limited capability to make moral decisions, arguing that they are in a stage of development of their autonomy and therefore their ability to agree should be related to their degree of moral maturity (Gracia et al., 2001).

In the same way, other studies mention the ability of children to understand issues related to the research or procedure that will be carried out, as long as it is informed to the minor with a simple and appropriate language, for example: children with ages of 6 years old showed a reasonable understanding to the clinical or investigative procedures, although it is emphasized that the logic of understanding is greater the older the child is (Hurley \& Underwood, 2002; Kaser-Boyd, Adelman, Taylor, \& Nelson, 1986; Kaser-Boyd et al., 1986). Legally in many Latin-American and European countries the minor's legal ability to consent depends a lot on the degree of emancipation and the age, where countries like Colombia and France consider it from the age of 18 (Krauskopf, 2011, pp. 51-70).

\subsection{Assent: Deliberate or Decide}

Between the child and the clinicians there must be an articulated dialogue where the child is considered as a recognized moral subject to assent even consent, when moral maturity is proven in the decision making process with a high degree of responsibility in relation to its own self-care (Power, Higgins, \& Kohlberg, 1991), that is to say; a relation of deliberative power articulated to a rational communication model contextualized to socio-cultural aspects between the doctor, minor and legal guardian (Kuther, 2003; Reubi, 2012, pp. 348-68).

\section{The Informed Consent in the Minor Subject of Biomedical Research}

The scope of biomedical research has expanded greatly, in relation to studying populations considered vulnerable such as pregnant women and children (Díaz, 2009), by this means more attention should be paid in relation to topics related to methodological aspects related to recruitment and withholding of participants, instrumentation and data collection (Flaskerud \& Winslow, 1998), as well as certain aspects of the individual being present in the child, such as: confusion feelings, fear, apprehension of the unknown, loss, sadness, anxiety and stress, among others (Bruskas, 2008).

The research carried out at the present time in children and adolescents extends from the simple clinical observation of epidemiological data collection, to genetic studies to analyze the molecular mechanisms, as well as the evaluation of therapeutic interventions effects by clinical trials. (Bueno \& Ramos, 2000; Caldwell, Murphy, Butow, \& Craig, 2004; Guillén, 1997).

It has been demonstrated that the problem of taking assent does not lie only in a lack of academic training in bioethics, since most clinicians and researchers have it, but in a lack of acknowledgement of the child subjected to clinical trial as it is exposed by (Meisel, 1979; Cortés, 2009), definitively, to encourage the minor to make a free, autonomous and competent decision, and not simply consider him/her incapable of making decisions, transgressing his autonomy and dignity simply because of his/her age (Jacob, 2005, pp. 156-157).

So far there is no precise way to determine the maturity of a underage person (González, 1996; Derish \& Heuvel, 2000), but something else is when considering them capable of expressing their consent as has been indicated with some examples that describe the capability to consent from the age of 12 , and to assent from the age of 6 , bearing in mind their moral development and socio-cultural context as described by Aierbe, Cortés, \& Medrano (2001). In the end, neither of the both statements does not exclude the need to recognize them and be taken into account to 
make decisions that affect them directly in relation to their expectations and fears. Taking into account the most important, the fact of the lack of maturity in the child, should not be considered as a reason for not giving consent, since it is a moral obligation on the part of the doctor and the researcher to inform the child using appropriate strategies so that he/she understands at least the risks, by means of visual strategies and language regulation, to reach his/her maximum comprehension of the facts of the illness that may affect him/her in the short, medium and long term (Paling, 2003, pp. 745-747). Even some practices are being applied, where children older than 12 years must give their written consent (Levy, Larcher, Kurz, \& others, 2003). It is noted that the child over 16 years old and emancipated, could give their consent personally, for this the child must receive an explanation, appropriate to his/her age and ability to understand certain topics, such as elements of the study, the time that will last and the discomfort that the study will cause (Bioethics \& others, 1995; Levy et al., 2003; Hansen, 2016).

Ethical considerations with regard to biomedical research with children must be approved by an ethics committee, which must ensure, among other things, the application of assent, with the exception of over 16 years old emancipated people, it must be explained to the minor what it is intended to be done and finally, it must be justified the importance of the benefit that the child will receive (Tealdi \& Mainetti, 1990, p. 6; Prieto, 2015)

It should be noted that the main idea of the regulations and the doctrine of the mature minor is to keep in mind that regardless of the minor's age, they have the right to be informed (Barbero, 2006).

\subsection{The Mature Minor and His Right to be Informed}

In the United States of America, the Academy of Pediatrics asked the FDA to implement measures to generate scientifically supported information, which allows them to prescribe with more accuracy and less legal risks when researches are carried out with children (Cardoso \& Calabró, 2005, pp. 46-50). The Directive 2001/20/EC of the European Union states that: "People who are not in a position to give their consent to participate in a clinical trial must receive special protection" ... "These people should not be included in trials if the same results can be obtained with people capable of giving their consent" (Perez-Mana, Llonch, \& Farré, 2012).

The informed assent as a process should help to provide the elements to assess whether a minor is mature or not to agree or consent, when appropriate information is provided and in the most correct manner (Domínguez, 2006; Oppliger \& Bascuñán, 2011), which is an element of ethical responsibility on the researcher or clinician side, due until now international regulations do not have a consensus when the child has the full right to give their autonomous consent (Kunin, 1997). It could be said that the assent is the approval, but consent is an agreement between parties (Cardoso \& Calabró, 2005). Physicians and researchers have a moral obligation to listen carefully to the opinions and wishes of children who cannot give their full consent and should strive to obtain their assent, as well as the responsibility to determine the child's ability and competence to give his/her consent or assent; therefore, promote and protect the dignity, privacy and confidentiality of the child and the family (Levy et al., 2003).

\section{Conclusions}

In the last century a great importance has been given to the subject of the minor's capacity to make moral decisions in relation to their health and to participate in biomedical research studies, there are even multiple methodologies with an ethical basis from the moral and practical point of view as an approach in the measurement of the minor's capability to be consider as mature when assenting or consenting. Possibly the practices of the clinicians focus more on their perception regarding the autonomy of the child or his degree of emancipation.

The informed consent as inclusive process must enact the development of autonomy and self-determination of the minor, where bioethics has been offering a framework for analysis, for a real communication process that recognizes the minor as a moral subject worthy of information and respect, beyond legal formalism.

It is important that the proposed researches in children should be evaluated and adjusted to national and international protocols, in addition to researchers and clinicians to promote child's autonomy, respect and dignity from the same practices when referring or requiring informed consent.

\section{Competing Interests Statement}

The authors declare that there are no competing or potential conflicts of interest.

\section{References}

Aierbe, A., Cortés, A., \& Medrano, C. (2001). Una visión integradora de la teoría kohlberiana a partir de las críticas contextuales: implicaciones para la educación y la investigación en el ámbito moral. Cultura y Educación, 13(2), 147-177. https://doi.org/10.1174/113564001750425123 
Alderson, P. (2007). Competent children? Minors' consent to health care treatment and research. Social science \& medicine, 65(11), 2272-2283. https://doi.org/10.1016/j.socscimed.2007.08.005

Appelbaum, P. S., \& Roth, L. H. (1982). Competency to consent to research: A psychiatric overview. Archives of General Psychiatry, 39(8), 951-958. https://doi.org/10.1001/archpsyc.1982.04290080061009

Aresté, M. E., Paradero, J. P., \& Fernández, E. M. (2013). La capacidad de decisión en el menor. Aspectos particulares de la información en el niño y en el joven. Anales de Pediatría Continuada, 11(4), 204-211. https://doi.org/10.1016/S1696-2818(13)70139-2

Barbero, J. (2006). El derecho del paciente a la información: el arte de comunicar. En Anales del sistema sanitario de Navarra (Vol. 29, pp. 19-27). SciELO Espana. https://doi.org/10.4321/S1137-66272006000600003

Bioethics, C. on, \& others. (1995). Informed consent, parental permission, and assent in pediatric practice. Pediatrics, 95(2), 314-317.

Blázquez, F. O. (2014). El menor maduro ante el derecho. Competencia, capacidad, autonomía. https://doi.org/10.13184/eidon.41.2014.28-52

Bruskas, D. (2008). Children in foster care: A vulnerable population at risk. Journal of Child and Adolescent Psychiatric Nursing, 21(2), 70-77. https://doi.org/10.1111/j.1744-6171.2008.00134.x

Bueno, M., \& Ramos, F. J. (2000). Bioética, genética y pediatría. An Esp Pediatr, 52(551), 30-33.

Caldwell, P. H., Murphy, S. B., Butow, P. N., \& Craig, J. C. (2004). Clinical trials in children. The Lancet, 364(9436), 803-811. https://doi.org/10.1016/S0140-6736(04)16942-0

Cardoso, P. C., \& Calabró, P. D. (2005). Investigación clínica farmacológica en pediatría:?` Es ético y legal experimentar en niños?(Parte 1). Archivos argentinos de pediatría, 103(1), 46-50.

Cortés, N. (2009). El pronóstico: un compromiso ético fundamental para el consentimiento informado. Revista Facultad de Odontología Universidad de Antioquia, 18(1). Retrieved from https://aprendeenlinea.udea.edu.co/revistas/index.php/odont/article/view/3099

Derish, M. T., \& Heuvel, K. V. (2000). Mature minors should have the right to refuse life-sustaining medical treatment. The Journal of Law, Medicine \& Ethics, 28(2), 109-124. https://doi.org/10.1111/j.1748-720X.2000.tb00001.x

Díaz, B. O., \& Pérez, C. G. (2007). Consentimiento informado y capacidad para decidir del menor maduro. Pediatría integral, 10, 877-883.

Díaz, F. A. G. (2009). Aspectos bioéticos del consentimiento informado en investigación biomédica con población vulnerable. Revista Latinoamericana de bioética, 9(17), 8-27.

Domínguez, M. E. (2006). El consentimiento informado en la clínica con niños. Paradigmas, Métodos y Técnicas. Memorias XIII Jornadas de Investigación. Facultad de Psicología, Universidad de Buenos Aires. Buenos Aires, 10(11), 388-391.

Drane, J. F. (1999). Las múltiples caras de la competencia. En Bioética para clínicos (pp. 163-176). Editorial Triacastela.

Ecoffey, C., \& Dalens, B. (2003). Informed consent for children. Current Opinion in Anesthesiology, 16(2), 205-208. https://doi.org/10.1097/00001503-200304000-00015

Flaskerud, J. H., \& Winslow, B. J. (1998). Conceptualizing vulnerable populations health-related research. Nursing research, 47(2), 69-78. https://doi.org/10.1097/00006199-199803000-00005

Fluke, J. D., Baumann, D. J., Dalgleish, L. I., \& Kern, H. D. (2014). Decisions to protect children: A decision making ecology. En Handbook of child maltreatment (pp. 463-476). https://doi.org/10.1007/978-94-007-7208-3_25

González, J. J. Z. (1996). Creencias sobre la madurez psicológica y desarrollo adulto. Anales de psicología, 12(1), 41.

Goodwin, M., \& Duke, N. (2011). Capacity and autonomy: a thought experiment on minors' access to assisted reproductive technology. Retrieved from https://papers.ssrn.com/soL3/papers.cfm?abstract_id=1933829

Gracia, D., Jarabo, Y., Espíldora, N. M., Ríos, J., \& others. (2001). Toma de decisiones en el paciente menor de edad. Medicina clínica, 117(5), 179-190. https://doi.org/10.1016/S0025-7753(01)72054-4

Guillén, D. G. (1997). Bioética y pediatría. Rev Esp Pediatr, 53(2), 99-106. 
Guirao-Goris, J. A., Olmedo Salas, A., \& Ferrer Ferrandis, E. (2008). El artículo de revisión. Revista Iberoamericana de Enfermería Comunitaria, 1(1), 1-25.

Hansen, T. W. R. (2016). Patient autonomy-what does it mean for clinical decision-making in children and adolescents? INTERNATIONAL ADVISORS, 3.

Hurley, J. C., \& Underwood, M. K. (2002). Children's understanding of their research rights before and after debriefing: Informed assent, confidentiality, and stopping participation. Child development, 73(1), 132-143. https://doi.org/10.1111/1467-8624.00396

Jacob, M. S. (2005). El menor maduro. Boletín de Pediatría, 45(193), 156-160.

Kaser-Boyd, N., Adelman, H. S., Taylor, L., \& Nelson, P. (1986). Children's understanding of risks and benefits of psychotherapy. Journal of Clinical Child Psychology, 15(2), 165-171. https://doi.org/10.1207/s15374424jccp1502_9

King, N. M., \& Cross, A. W. (1989). Children as decision makers: guidelines for pediatricians. The Journal of pediatrics, 115(1), 10-16. https://doi.org/10.1016/S0022-3476(89)80321-X

Krauskopf, D. (2011). Enfoques y dimensiones para el desarrollo de indicadores de juventud orientados a su inclusión social y calidad de vida. Ultima década, 19(34), 51-70. https://doi.org/10.4067/S0718-22362011000100004

Kunin, H. (1997). Ethical issues in pediatric life-threatening illness: dilemmas of consent, assent, and communication. Ethics \& behavior, 7(1), 43-57. https://doi.org/10.1207/s15327019eb0701_4

Kuther, T. L. (2003). Medical decision-making and minors: issues of consent and assent. Adolescence, 38(150), 343.

Levy, M. D. L., Larcher, V., Kurz, R., \& others. (2003). Informed consent/assent in children. Statement of the Ethics Working Group of the Confederation of European Specialists in Paediatrics (CESP). European journal of pediatrics, 162(9), 629-633. https://doi.org/10.1007/s00431-003-1193-z

Lyon, R.-M. (1987). Speaking for a Child: The Role of Independent Counsel for Minors. California Law Review, 75(2), 681-706. https://doi.org/10.2307/3480627

Martínez, J. L. C., \& others. (2001). Ética a Nicómaco. Alianza Editorial. Retrieved from https://dialnet.unirioja.es/servlet/libro? codigo $=292204$

Meisel, A. (1979). The exceptions to the informed consent doctrine: striking a balance between competing values in medical decisionmaking. Wis. L. Rev., 413.

Morrow, V., \& Richards, M. (1996). The ethics of social research with children: an overview. Children \& society, 10(2), 90-105. https://doi.org/10.1002/(SICI)1099-0860(199606)10:2\%3C90::AID-CHI14\%3E3.0.CO;2-Z

Oppliger, W., \& Bascuñán, M. (2011). Consentimiento informado: Percepción de médicos, enfermeras y padres sobre el proceso comunicativo. Revista chilena de pediatría, 82(3), 204-210. https://doi.org/10.4067/S0370-41062011000300005

Owens, H. (1977). When is a voluntary commitment really voluntary? American Journal of Orthopsychiatry, 47(1), 104. https://doi.org/10.1111/j.1939-0025.1977.tb03250.x

Paling, J. (2003). Strategies to help patients understand risks. British Medical Journal, 327(7417), 745. https://doi.org/10.1136/bmj.327.7417.745

Perez-Mana, C., Llonch, C., \& Farré, M. (2012). Transparencia en la investigación clínica: registro de los ensayos clínicos y publicación de resultados. Medicina Clínica, 139(13), 593-597. https://doi.org/10.1016/j.medcli.2012.06.009

Power, F. C., Higgins, A., \& Kohlberg, L. (1991). Lawrence Kohlberg's approach to moral education. Columbia University Press.

Prieto, P. (2015). Comités de ética en investigación con seres humanos: relevancia actual en Colombia. Experiencia de la Fundación Santa Fe de Bogotá. Acta Médica Colombiana, 40(2), 50-56.

Reubi, D. (2012). The human capacity to reflect and decide: Bioethics and the reconfiguration of the research subject in the British biomedical sciences. Social Studies of Science, 42(3), 348-368. https://doi.org/10.1177/0306312712439457

Roth, L. H., Appelbaum, P. S., Sallee, R., Reynolds, C. F., \& Huber, G. (1982). The dilemma of denial in the 
assessment of competency to refuse treatment. Am J Psychiatry, 139(7), 910-913. https://doi.org/10.1176/ajp.139.7.910

Tealdi, J. C., \& Mainetti, J. A. (1990). Los comités hospitalarios de ética. Retrieved from http://hist.library.paho.org/Spanish/BOL/v108n(5-6)p431.pdf

Weithorn, L. A., \& Campbell, S. B. (1982). The competency of children and adolescents to make informed treatment decisions. Child development, 1589-1598. https://doi.org/10.2307/1130087

Wendler, D., \& Shah, S. (2003). Should children decide whether they are enrolled in nonbeneficial research? American Journal of Bioethics, 3(4), 1-7. https://doi.org/10.1162/152651603322614382

Witholding.pdf_40818793.pdf. (s. f.). Retrieved from http://www.gmc-uk.org/Witholding.pdf_40818793.pd

\section{Copyrights}

Copyright for this article is retained by the author(s), with first publication rights granted to the journal.

This is an open-access article distributed under the terms and conditions of the Creative Commons Attribution license (http://creativecommons.org/licenses/by/4.0/). 